\title{
A STUDY ON LEACHATE CHARACTERISTICS GENERATED FROM WASTE FOUNDRY SAND AND ITS IMPACT ON WATER BODIES
}

\author{
Deepak Rotti ${ }^{1}$, R B. Gadag ${ }^{2}$ \\ ${ }^{1}$ M.Tech, student, Environmental Engineering, KLE's Dr. MSSCET, Belagavi, Karnataka, India. \\ ${ }^{2}$ R B. Gadag, Associate Professor, Dept. of Civil Engineering, KLE's Dr. MSSCET, Belagavi, Karnataka, India.
}

\begin{abstract}
Metal foundry industries use sand as the major part in the metal casting process. Foundry industries are the industries which mould the metal (alloy) castings, the castings are casted by using the molten metals, which are poured into the moulds prepared by the sand (usually known as foundry sand), and here the foundry sand is subjected to the temperature which is higher than $1000^{\circ} \mathrm{C}$ in the moulding process. The waste sand obtained after the casting, cannot be used further and thus the Waste Foundry Sand (WFS) is removed from the foundry industry and it is known as waste foundry sand. Waste foundry sand generated from the metal foundries is indiscriminately dumped in the low lying areas of Belagavi city. Belagavi city receives high annual rainfall around $1200 \mathrm{~mm}$. The WFS dumped contains the heavy metal concentrations. Leachate is generated from the WFS containing heavy metals and the heavy metals are leached from the WFS, thus the ground water is contaminated. Water samples from a lake, 5 open wells and a bore well in the Udyambag area were collected and analyzed for Physico-chemical characteristics and heavy metal concentrations. The leaching effect of the WFS is analyzed using TCLP. The leaching effect of the WFS is also studied when it is a part of pervious concrete and the heavy metal analysis is carried out. The ground water and surface water body study includes the Physico-chemical parameters like chlorides, TDS, SC, pH, turbidity, colour, odour, temperature and the heavy metals like barium, total chromium, iron, lead and manganese.
\end{abstract}

Key Words: Waste foundry sand, Heavy metals, Leachate characteristics, Ground water.

\section{INTRODUCTION}

Metal foundry industries use sand as the major part in the metal casting process. Foundry industries are the industries which mould the metal castings, the castings are casted by using the molten metals, which are poured into the moulds prepared by the sand, and here the foundry sand is subjected to the temperature which is higher than $1000^{\circ} \mathrm{C}$ in the moulding process. The waste sand obtained after the casting, cannot be used further and thus the Waste Foundry Sand (WFS) is removed from the foundry industry and it is known as waste foundry sand. WFS comprise of high silica content and thus is the by-product of the ferrous and nonferrous metal castings. Metal castings are based on the type of the metal to be manufactured/casted in the industry, to be precise, iron and steel from ferrous metal group and aluminium, copper, brass and bronze from non-ferrous metal group. ${ }^{[1]}$

As the quantity of Waste Foundry Sand is generated in huge amount, only a part of WFS is considered as the hazardous waste and the rest of the part is considered as non-hazardous industrial waste foundry sand. As the WFS is generated 0610 million metric tons annually, only some part of the WFS is reused as the construction material, in various applications such as construction field, as sub-base material in road beds and parking lots and as in pipe beddings. ${ }^{[2]}$

\subsection{Waste Foundry Sand}

The large amount of users or generators of the WFS are the automobile manufacturing industries and the spare parts manufacturing industries. Waste foundry sand is composed of uniformly sized, high quality silica sand, which is used in making moulds for casting the ferrous and non-ferrous metal moulds. The raw foundry sand used in the foundry industry exhibits high quality than the normal sand, which is used for the construction purpose. The WFS which is processed in mould making is reused by recycling it again the casting process and thus the recycled sand gradually looses its property and gets degraded when used multiple times. Thus the degraded sand or poor quality sand (many times used or recycled) cannot be used further in the industry and hence it is discarded as a waste material, this may be termed as Waste Foundry Sand. The properties of the foundry sand such as physical and chemical properties, depends on the type of binder used or type of the process involved and depending upon the industry type. ${ }^{[3]}$

\subsubsection{Physical properties of WFS}

Considering the appearance of the waste foundry sand, the clay bonded or green sand appears in black or grey colour, and the chemically binded foundry sand appears in whitish tan colour. The shape of the foundry sand is usually semiangular to round in the appearance. The waste foundry sand has uniform grain distribution, in which $85 \%$ to $95 \%$ of the particles are between $0.6 \mathrm{~mm}$ to $0.15 \mathrm{~mm}$ and $5 \%$ to $12 \%$ may be tiny in size than $0.075 \mathrm{~mm} .^{[4]}$ 
Table 1.1 Typical physical properties of WFS

\begin{tabular}{|c|c|c|}
\hline Property & Range & Test Method \\
\hline Specific gravity & $2.39-2.55$ & ASTM D854 \\
\hline $\begin{array}{c}\text { Bulk relative density in } \\
\mathrm{kg} / \mathrm{m}^{3}\end{array}$ & 2589 & $\begin{array}{c}\text { ASTM C48/AASHTO } \\
\text { T } 84\end{array}$ \\
\hline Absorption in $\%$ & 0.45 & ASTM C128 \\
\hline Moisture content in $\%$ & $0.1-10.1$ & ASTM D2216 \\
\hline $\begin{array}{c}\text { Coefficient of } \\
\text { permeability in (cm } / \mathrm{sec})\end{array}$ & $10^{-3}-10^{-6}$ & $\begin{array}{c}\text { AASHTO T 215/ASTM } \\
\text { D2434 }\end{array}$ \\
\hline $\begin{array}{c}\text { Plastic limit/plastic } \\
\text { index }\end{array}$ & Non-plastic & $\begin{array}{c}\text { AASHTO T90/ASTM } \\
\text { D4318 }\end{array}$ \\
\hline
\end{tabular}

\subsubsection{Chemical properties of WFS}

The waste foundry sand chemical composition is dependent on the type of the binder used, and the type of the combustible used and the type of the metal castings which are been casted in the foundry industry. The chemical composition of the foundry sand may influence the efficiency of the foundry sand. After the casting of the moulds, the burnt foundry sand mainly consists of silica sand, which is bounded by a thin layer of burnt carbon traces, and it also contains the residual binder, namely bentonite and the foundry dust. Above mentioned factors contribute to the chemical composition of the waste foundry sand. ${ }^{[4]}$

Table 1.2 Typical Chemical composition of WFS. [5]

\begin{tabular}{|l|l|}
\hline \multicolumn{1}{|c|}{ Constituents } & \multicolumn{1}{c|}{ \% in WFS } \\
\hline $\mathrm{SiO}_{2}$ & 87.91 \\
\hline $\mathrm{Al}_{2} \mathrm{O}_{3}$ & 4.70 \\
\hline $\mathrm{Fe}_{2} \mathrm{O}_{3}$ & 0.94 \\
\hline $\mathrm{MgO}$ & 0.30 \\
\hline $\mathrm{K}_{2} \mathrm{O}$ & 0.25 \\
\hline $\mathrm{Na}_{2} \mathrm{O}$ & 0.19 \\
\hline $\mathrm{TiO}_{2}$ & 0.15 \\
\hline $\mathrm{CaO}$ & 0.14 \\
\hline $\mathrm{SO}_{3}$ & 0.09 \\
\hline
\end{tabular}

\subsubsection{Leachate}

"Leachate may be defined as the liquid which drains/leaches from the solid wastes which are disposed" (Henry and Heinke, 1996).
The principle which is involved in the formation of leachate is by precipitation and percolation. The leachate is formed/generated from the wastes which are disposed openly and indiscriminately in the open spaces or environment or which are disposed in the landfills. The composition of leachate varies with respect to the type of the waste disposed and depending on the age of the waste disposed. The leachate may be composed of the dissolved particulate matter or suspended particulate matter. If the leachate comes in contact with the ground water bodies or surface water bodies present in the environment, the water gets contaminated and the quality of the water degrades, thus the contaminated water will be unfit for the usage in the domestic purposes. ${ }^{[5]}$

\subsubsection{Composition of leachate}

Leachate may be characterized as the water based solution, the leachate coming out from the typical landfill is stronglyoffensive odour and it appears to be yellow or dark grey colour. The odour of the leachate is acidic and pervasive because of the presence of sulphur, organic compounds, nitrogen and hydrogen.

Leachate may be differentiated into four categories of contaminants, they are

[1]. Dissolved oxygen matter.

[2]. Inorganic macro compounds

[3]. Heavy metals

[4]. Xenobiotic organic compounds

In the above mentioned categories, the dissolved organic matter may be composed of aldehydes, acids, alcohols, short chain sugars etc. And in the category of inorganic macro compounds it may have the composition of common cations and common anions including sulphate, iron, chloride, ammonia, zinc and aluminium. In the third group of heavy metals, it may contain iron, nickel, copper, lead etc. Lastly in the fourth group of xenobiotic organic compounds it may contain the compounds of halogenated organics. ${ }^{[5]}$

\section{MATERIALS AND METHODOLOGY}

\subsection{Leachate Extraction by Toxicity Characteristic}

\section{Leaching Procedure (TCLP) method.[6]}

TCLP is a commonly used test to determine the leaching characteristics. The TCLP test is the United States Environmental Protection Agency (USEPA) leaching procedure for determining the characteristics of hazardous waste. Many state regulatory agencies have adopted the TCLP for characterization of solid wastes. TCLP involves a 20:1 liquid to solid ratio, test was designed to simulate leaching under waste disposal conditions. The test involves two leaching solutions, alkaline materials use a solution that has a $\mathrm{pH}$ of 2.88 , which is buffered using acetic acid and the less alkaline materials use a solution with a $\mathrm{pH}$ of 4.93 which is buffered using sodium hydroxide (Douglas, 2003). 


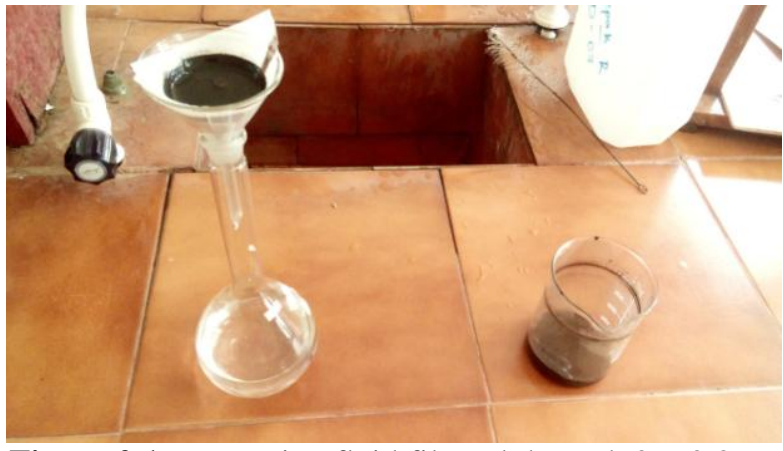

Figure 2.1: Extraction fluid filtered through $0.6-0.8 \mu \mathrm{m}$ glass fibre filter paper.

\subsection{Heavy metal analysis}

In flame atomic absorption spectrometry, an aqueous sample containing metal analyte is aspirated to a flame and atomized. Flame causes the evaporation of the solvent and accelerates the vaporization of the free metal atoms, and this is named as atomization, here, a light beam is directed through a flame into a monochromator/filter/slit and which is directed towards a photoelectric detector, which measures the amount of light absorbed by the freely atomized element in the flame. For some metals, this method exhibits superior sensitivity over flame emission, because each metal will be having its own characteristic absorption wavelength. A light source (hollow cathode lamp) composed of that element is used in the process ${ }^{[7]}$

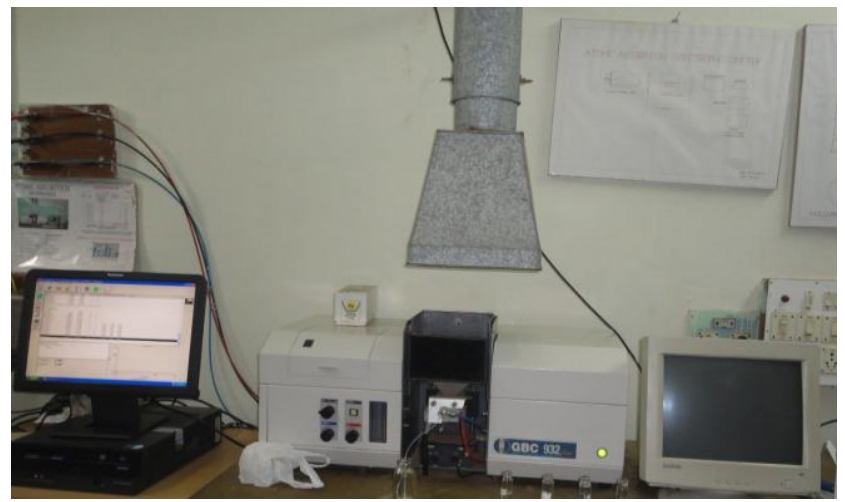

Figure 2.2: Atomic Absorption Spectrophotometer (AAS). 2.3 Sample Collection ${ }^{[7]}$

Sampling technique for sample collection.

Generally there are two types of sampling technique, which is used for the collection of the water and wastewater samplings for examining their physical and chemical characteristics. The two types of sampling are

- Grab sampling.

- Composite sampling.

\section{RESULTS AND DISCUSSIONS}

The following tables gives the analyzed results of the entire experimental work, that is, leachate analysis for heavy metal concentrations from raw leachate extract and samples collected from surface and subsurface water bodies, and the effects of open dumping of the waste foundry sand on surface water bodies and subsurface water bodies.
Table 3.1: Heavy metal concentrations in leachate.

\begin{tabular}{|l|l|l|l|l|l|}
\hline Sl.No & Parameters & April & May & June & Avg \\
\hline 1 & Arsenic & BDL & BDL & BDL & --- \\
\hline 2 & Barium & 0.0088 & 0.0091 & 0.0097 & 0.0092 \\
\hline 3 & Chloride & 66.33 & 66.96 & 67.02 & 66.77 \\
\hline 4 & Cadmium & BDL & BDL & BDL & --- \\
\hline 5 & Chromium & 0.0150 & 0.0169 & 0.0160 & 0.0159 \\
\hline 6 & Iron & 34.83 & 35.29 & 35.53 & 35.21 \\
\hline 7 & Lead & 0.075 & 0.079 & 0.077 & 0.77 \\
\hline 8 & Manganese & 3.169 & 3.453 & 3.621 & 3.41 \\
\hline 9 & Mercury & BDL & BDL & BDL & --- \\
\hline 10 & Selenium & BDL & BDL & BDL & --- \\
\hline 11 & Zinc & 0.5996 & 0.6010 & 0.6170 & 0.6058 \\
\hline
\end{tabular}

\subsection{Water sample analysis.}

The Physico-chemical analysis and heavy metal analysis was carried out for the water samples, collected from surface water body and subsurface water bodies, the tests were conducted for the water samples taken from

- Lake water (LW)

- Open Well (OW) water

- Bore Well (BW) water

\subsubsection{Physico-Chemical and heavy metal analysis}

\section{for lake water.}

The Physico-chemical analysis and heavy metal concentrations of the sample obtained from the lake water are given below in the table.

Table 3.2: Physico-Chemical \& Heavy metal analysis for lake water.

\begin{tabular}{|c|c|c|c|c|c|c|}
\hline Sl.No & Parameters & May & June & July & Avg & $\begin{array}{c}\text { DL } \\
\text { as } \\
\text { per } \\
\text { BIS, } \\
\text { mg/L }\end{array}$ \\
\hline 1 & $\begin{array}{c}\text { Temperature } \\
\left({ }^{\circ} \text { C) }\right.\end{array}$ & 23 & 20 & 21 & 21.33 & NG \\
\hline 2 & $\begin{array}{c}\text { Colour } \\
\text { (Hazen) }\end{array}$ & -- & -- & -- & -- & 5 \\
\hline 3 & Odour & -- & -- & -- & -- & A \\
\hline 4 & $\begin{array}{c}\text { Turbidity } \\
(\text { NTU) }\end{array}$ & 4.2 & 3.6 & 3.9 & 3.9 & 1 \\
\hline 5 & $\begin{array}{c}\text { Specific } \\
\text { Conductivity } \\
(\mu \text { S/cm) }\end{array}$ & 571.61 & 624.13 & 673.40 & 623.04 & NG \\
\hline 6 & TDS (mg/L) & 342.96 & 374.47 & 404.04 & 373.82 & 500 \\
\hline 7 & pH & 7.8 & 7.4 & 7.6 & 7.6 & $\begin{array}{c}6.5- \\
8.5\end{array}$ \\
\hline 8 & $\begin{array}{c}\text { Chloride } \\
(\text { mg/L) }\end{array}$ & 57.42 & 57.51 & 58.16 & 57.69 & 250 \\
\hline \multicolumn{7}{|c|}{ Heavy metal Concentrations for lake water in mg/L } \\
\hline 9 & Barium & 0.8623 & 0.8713 & 0.8727 & 0.8687 & 0.7 \\
\hline 10 & Chromium & BDL & BDL & BDL & --- & 0.05 \\
\hline 11 & Iron & 0.0289 & 0.0312 & 0.0351 & 0.0317 & 0.3 \\
\hline 12 & Lead & 0.0016 & 0.0021 & 0.0028 & 0.0021 & 0.01 \\
\hline 13 & Manganese & 0.0018 & 0.0020 & 0.0026 & 0.0021 & 0.1 \\
\hline 14 & Zinc & BDL & BDL & BDL & --- & 5.0 \\
\hline
\end{tabular}




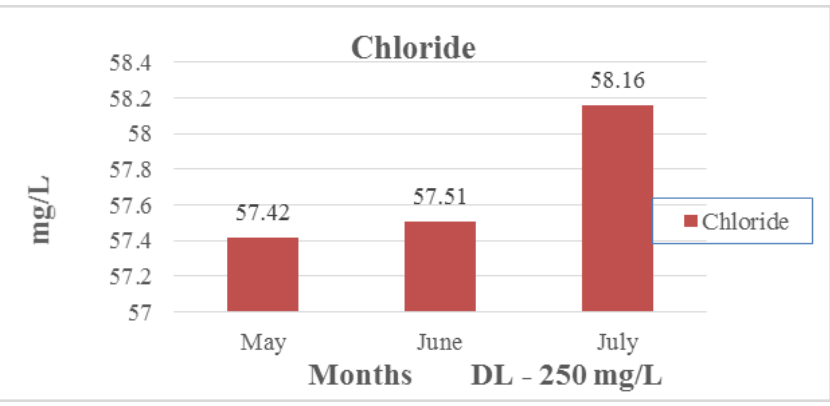

Figure 3.1: Chloride concentration in lake water.

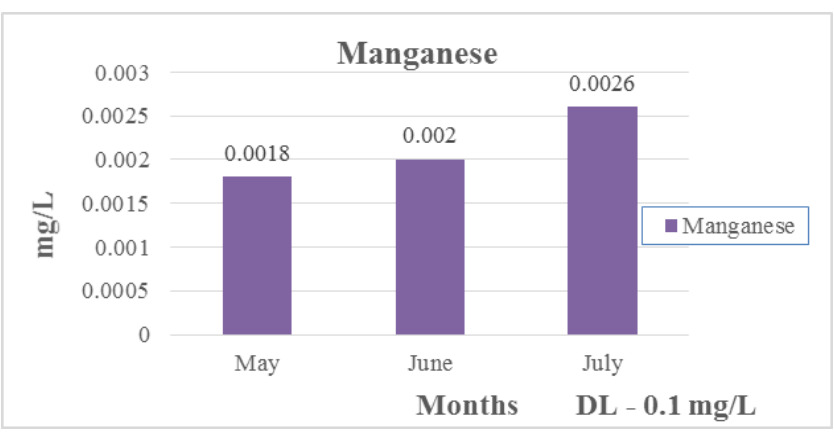

Figure 3.2: Manganese concentration in lake water.

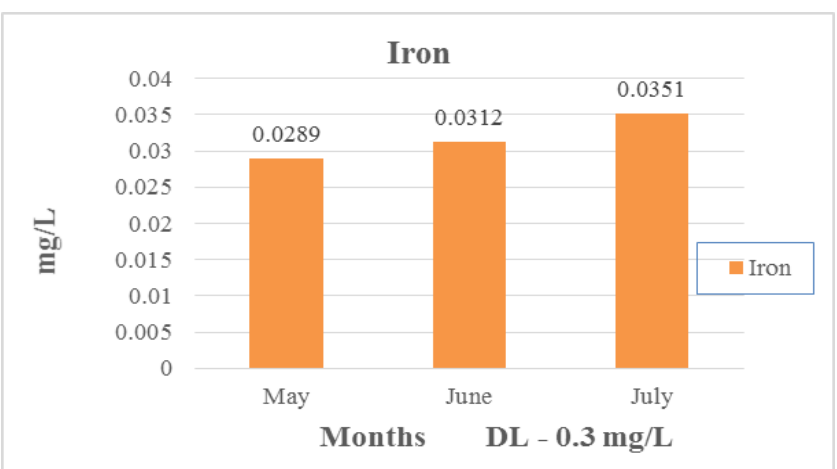

Figure 3.3: Iron concentration in lake water.

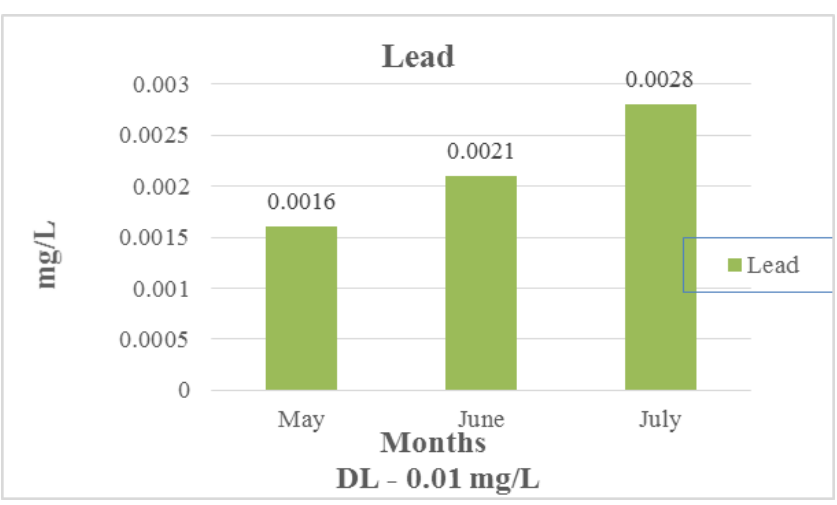

Figure 3.4: Lead concentration in lake water.

From the above figures $3.1,3.2,3.3$ and 3.4 it is seen that the samples of lake water, which is located at Sahyadri nagar, Udyambag, Belagavi, are well within the desirable limits of BIS during the study period. Hence the concentrations of Chloride, Manganese, Iron and Lead may not affect the health of the people.

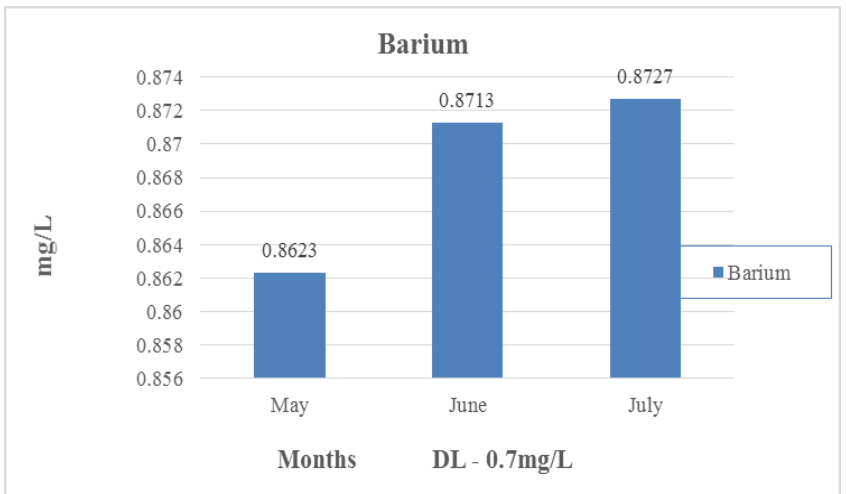

Figure 3.5: Barium concentration in lake water.

From the above figures 3.5 it is seen that the samples of lake water, which is located at Sahyadri nagar, Udyambag, Belagavi, is greater than the desirable limits of BIS during the study period. Hence it can be said that the water sample can closely affect the people who use it for drinking purposes. The long-time usage of this water can affect the people leading to cardiovascular problems.

\subsubsection{Physico-Chemical and heavy metal analysis for open well water.}

Table 3.3: Physico-Chemical \& Heavy metal analysis for open well water.(2)

\begin{tabular}{|c|c|c|c|c|c|c|}
\hline \\
\hline $\begin{array}{l}\text { Sl. } \\
\text { No }\end{array}$ & Parameters & May & June & July & Avg & $\begin{array}{c}\text { DL as } \\
\text { per } \\
\text { BIS, } \\
\text { mg/L }\end{array}$ \\
\hline 1 & $\begin{array}{c}\text { Temperature } \\
\left({ }^{\circ} \mathrm{C}\right)\end{array}$ & 18 & 19 & 17 & 18 & NG \\
\hline 2 & $\begin{array}{c}\text { Colour } \\
\text { (Hazen) }\end{array}$ & -- & -- & -- & -- & 5 \\
\hline 3 & Odour & -- & -- & -- & -- & A \\
\hline 4 & $\begin{array}{c}\text { Turbidity } \\
\text { (NTU) }\end{array}$ & 2.82 & 2.79 & 2.84 & 2.81 & 1 \\
\hline 5 & $\begin{array}{c}\text { Specific } \\
\text { Conductivity } \\
(\mu \mathrm{S} / \mathrm{cm})\end{array}$ & 459.3 & 455.8 & 453.5 & 456.2 & NG \\
\hline 6 & $\mathrm{TDS}(\mathrm{mg} / \mathrm{L})$ & 275.58 & 273.48 & 272.10 & 273.72 & 500 \\
\hline 7 & $\mathrm{pH}$ & 6.4 & 6.6 & 6.8 & 6.6 & $6.5-8.5$ \\
\hline 8 & $\begin{array}{c}\begin{array}{c}\text { Chloride } \\
(\mathrm{mg} / \mathrm{L})\end{array} \\
\end{array}$ & 74.33 & 75.17 & 76.07 & 75.19 & 250 \\
\hline \multicolumn{7}{|c|}{ Heavy metal Concentrations for open well water in $\mathrm{mg} / \mathrm{L}$} \\
\hline 9 & Barium & 0.036 & 0.041 & 0.062 & 0.046 & 0.7 \\
\hline 10 & $\begin{array}{c}\text { Total } \\
\text { Chromium } \\
\end{array}$ & 0.0019 & 0.0023 & 0.0029 & 0.0023 & 0.05 \\
\hline 11 & Iron & 0.0076 & 0.0082 & 0.0090 & 0.0082 & 0.3 \\
\hline 12 & Lead & BDL & BDL & BDL & -- & 0.01 \\
\hline 13 & Manganese & BDL & BDL & BDL & -- & 0.1 \\
\hline 14 & Zinc & BDL & BDL & BDL & -- & 5.0 \\
\hline
\end{tabular}


Table 3.4: Physico-Chemical \& Heavy metal analysis for open well water.(3)

\begin{tabular}{|c|c|c|c|c|c|c|}
\hline $\begin{array}{c}\text { Sl. } \\
\text { No }\end{array}$ & Parameters & May & June & July & Avg & $\begin{array}{c}\text { DL as } \\
\text { per } \\
\text { BIS, } \\
\text { mg/L }\end{array}$ \\
\hline 1 & $\begin{array}{c}\text { Temperature } \\
\left({ }^{\circ} \text { C) }\right.\end{array}$ & 17 & 18 & 16 & 17 & NG \\
\hline 2 & $\begin{array}{c}\text { Colour } \\
\text { (Hazen) }\end{array}$ & -- & -- & -- & -- & 5 \\
\hline 3 & Odour & -- & -- & -- & -- & A \\
\hline 4 & $\begin{array}{c}\text { Turbidity } \\
\text { (NTU) }\end{array}$ & 2.91 & 2.89 & 2.92 & 2.90 & 1 \\
\hline 5 & $\begin{array}{c}\text { Specific } \\
\text { Conductivity } \\
(\mu \text { S/cm) }\end{array}$ & 489.2 & 493.6 & 490.8 & 491.2 & NG \\
\hline 6 & \begin{tabular}{c} 
TDS (mg/L) \\
\hline 7
\end{tabular} & 293.52 & 296.16 & 294.48 & 294.72 & 500 \\
\hline 8 & $\begin{array}{c}\text { Chloride } \\
\text { (mg/L) }\end{array}$ & 73.26 & 74.03 & 74.88 & 74.05 & 250 \\
\hline \multicolumn{7}{|c|}{ Heavy metal Concentrations for open well water in mg/L } \\
\hline 9 & Barium & 0.029 & 0.047 & 0.058 & 0.044 & 0.7 \\
\hline 10 & $\begin{array}{c}\text { Total } \\
\text { Chromium }\end{array}$ & 0.0017 & 0.0022 & 0.0028 & 0.0022 & 0.05 \\
\hline 11 & Iron & 0.0080 & 0.0086 & 0.0094 & 0.0089 & 0.3 \\
\hline 12 & Lead & BDL & BDL & BDL & -- & 0.01 \\
\hline 13 & $\begin{array}{c}\text { Manganese } \\
14\end{array}$ & BDL & BDL & BDL & -- & 0.1 \\
\hline
\end{tabular}

Table 3.5: Physico-Chemical \& Heavy metal analysis for open well water.(4)

\begin{tabular}{|c|c|c|c|c|c|c|}
\hline $\begin{array}{l}\text { Sl. } \\
\text { No }\end{array}$ & Parameters & May & June & July & Avg & $\begin{array}{c}\text { DL as } \\
\text { per } \\
\text { BIS, } \\
\text { mg/L }\end{array}$ \\
\hline 1 & $\begin{array}{c}\text { Temperature } \\
\left({ }^{\circ} \mathrm{C}\right)\end{array}$ & 16 & 17 & 15 & 16 & NG \\
\hline 2 & $\begin{array}{l}\text { Colour } \\
\text { (Hazen) }\end{array}$ & -- & -- & -- & -- & 5 \\
\hline 3 & Odour & -- & -- & -- & -- & A \\
\hline 4 & $\begin{array}{l}\text { Turbidity } \\
\text { (NTU) }\end{array}$ & 2.74 & 2.72 & 2.78 & 2.74 & 1 \\
\hline 5 & $\begin{array}{c}\text { Specific } \\
\text { Conductivity } \\
(\mu \mathrm{S} / \mathrm{cm})\end{array}$ & 439.6 & 430.3 & 443.8 & 437.9 & NG \\
\hline 6 & TDS (mg/L) & 263.76 & 258.18 & 266.28 & 262.74 & 500 \\
\hline 7 & $\mathrm{pH}$ & 7.5 & 7.4 & 6.9 & 7.2 & $6.5-8.5$ \\
\hline 8 & $\begin{array}{l}\text { Chloride } \\
\text { (mg/L) }\end{array}$ & 76.43 & 77.15 & 77.63 & 77.07 & 250 \\
\hline \multicolumn{7}{|c|}{ Heavy metal Concentrations for open well water in $\mathrm{mg} / \mathrm{L}$} \\
\hline 9 & Barium & 0.042 & 0.067 & 0.078 & 0.062 & 0.7 \\
\hline 10 & $\begin{array}{c}\text { Total } \\
\text { Chromium }\end{array}$ & 0.0026 & 0.0032 & 0.0038 & 0.0032 & 0.05 \\
\hline 11 & Iron & 0.0082 & 0.0091 & 0.012 & 0.0097 & 0.3 \\
\hline 12 & Lead & BDL & BDL & BDL & -- & 0.01 \\
\hline 13 & Manganese & BDL & BDL & BDL & -- & 0.1 \\
\hline 14 & Zinc & BDL & BDL & BDL & -- & 5.0 \\
\hline
\end{tabular}

Table 3.6: Physico-Chemical \& Heavy metal analysis for open well water.(5)

\begin{tabular}{|c|c|c|c|c|c|c|}
\hline $\begin{array}{l}\text { Sl. } \\
\text { No }\end{array}$ & Parameter & May & June & July & Average & $\begin{array}{c}\text { DL } \\
\text { as } \\
\text { per } \\
\text { BIS, } \\
\text { mg/L }\end{array}$ \\
\hline 1 & $\begin{array}{c}\text { Temperature } \\
\left({ }^{\circ} \mathrm{C}\right)\end{array}$ & 18 & 16 & 15 & 16.3 & NG \\
\hline 2 & $\begin{array}{c}\text { Colour } \\
\text { (Hazen) }\end{array}$ & -- & -- & -- & -- & 5 \\
\hline 3 & Odour & -- & -- & -- & -- & A \\
\hline 4 & $\begin{array}{l}\text { Turbidity } \\
\text { (NTU) }\end{array}$ & 2.89 & 2.86 & 2.88 & 2.87 & 1 \\
\hline 5 & $\begin{array}{c}\text { Specific } \\
\text { Conductivity } \\
(\mu \mathrm{S} / \mathrm{cm})\end{array}$ & 478.7 & 481.3 & 477.6 & 479.2 & NG \\
\hline 6 & TDS (mg/L) & 287.22 & 288.78 & 286.56 & 287.52 & 500 \\
\hline 7 & $\mathrm{pH}$ & 7.2 & 6.6 & 6.9 & 6.9 & $\begin{array}{l}6.5- \\
8.5\end{array}$ \\
\hline 8 & $\begin{array}{l}\text { Chloride } \\
(\mathrm{mg} / \mathrm{L})\end{array}$ & 74.71 & 75.21 & 75.83 & 75.25 & 250 \\
\hline \multicolumn{7}{|c|}{ Heavy metal Concentrations for open well water in $\mathrm{mg} / \mathrm{L}$} \\
\hline 9 & Barium & 0.031 & 0.044 & 0.057 & 0.044 & 0.7 \\
\hline 10 & $\begin{array}{c}\text { Total } \\
\text { Chromium }\end{array}$ & 0.0014 & 0.0019 & 0.0020 & 0.0017 & 0.05 \\
\hline 11 & Iron & 0.0082 & 0.0089 & 0.0098 & 0.0089 & 0.3 \\
\hline 12 & Lead & BDL & BDL & BDL & -- & 0.01 \\
\hline 13 & Manganese & BDL & BDL & BDL & -- & 0.1 \\
\hline 14 & Zinc & BDL & BDL & BDL & -- & 5.0 \\
\hline
\end{tabular}

The Barium, Chloride, Total Chromium and iron concentration values obtained for the Open well water samples collected during the study period are given below.

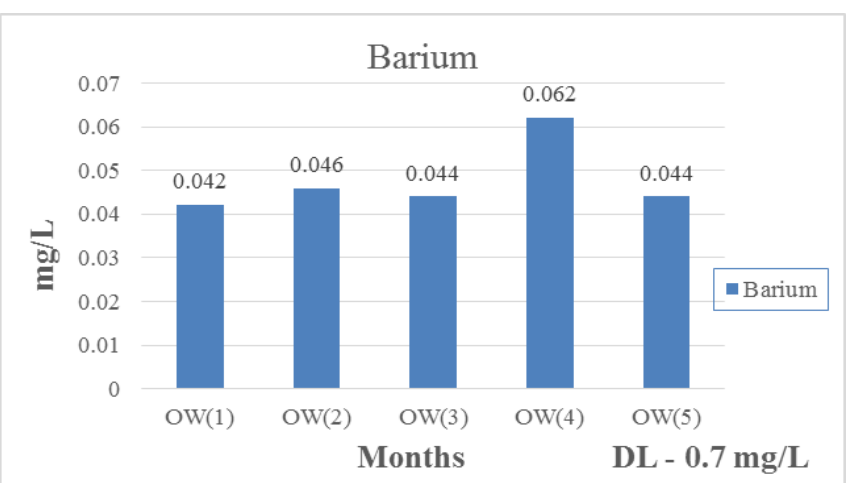

Figure 3.6: Barium concentration in Open Well water.

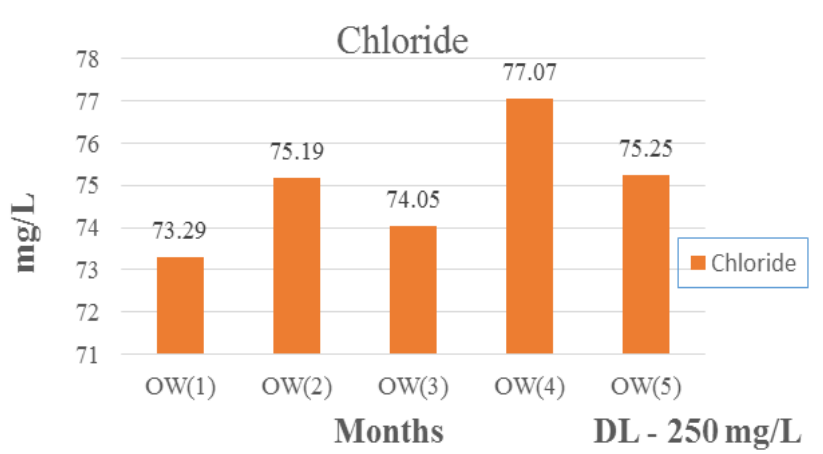

Figure 3.7: Chloride concentration in Open well water. 


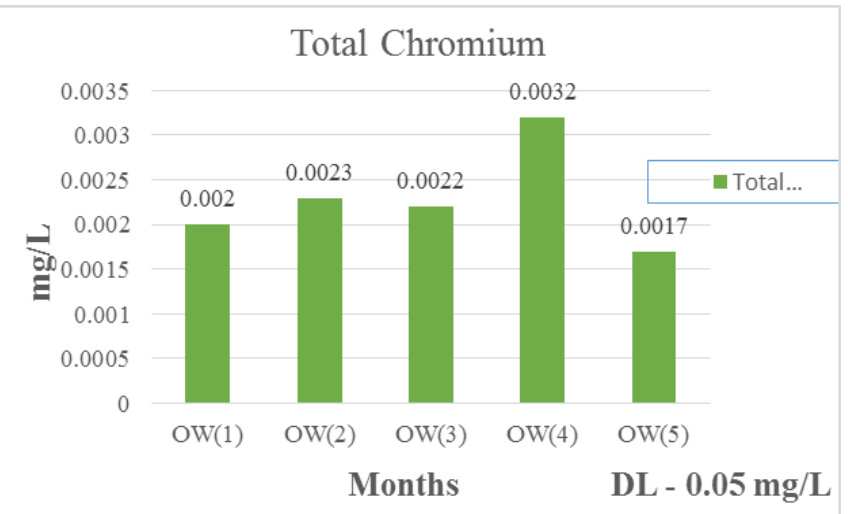

Figure 3.8: Total Chromium concentration in Open well water.

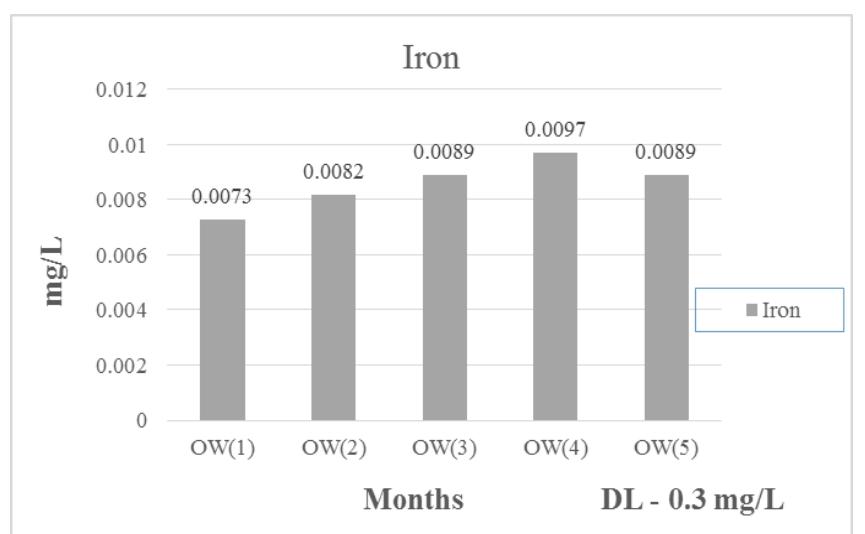

Figure 3.9: Iron concentration in Open well water.

From the above figures 5 . it is seen that the samples of Open well water, the Barium Chloride, Total Chromium and Iron concentrations is well within the the desirable limits of BIS during the study period. Hence the concentrations of Barium, Chloride, Total Chromium and Iron may not affect the health of the people. Lead, Manganese and Zinc concentrations in the open well water are below detectable level Hence the Concentrations of above mentioned Heavy metals does not affect the water and the health of the people using it for their daily usage.

\subsubsection{Physico-Chemical and heavy metal analysis}

\section{for bore well water.}

Table 3.7: Physico-Chemical \& Heavy metal analysis for Bore well water.(1)

\begin{tabular}{|c|c|c|c|c|c|c|}
\hline $\begin{array}{c}\text { SI. } \\
\text { No }\end{array}$ & Parameter & June & July & Aug & Avg & $\begin{array}{c}\text { DL as } \\
\text { per } \\
\text { BIS, } \\
\mathbf{m g} / \mathbf{L}\end{array}$ \\
\hline 1 & $\begin{array}{c}\text { Temperature } \\
\left({ }^{\circ} \text { C) }\right.\end{array}$ & 15 & 17 & 16 & 16 & NG \\
\hline 2 & $\begin{array}{c}\text { Colour } \\
\text { (Hazen) }\end{array}$ & -- & -- & -- & -- & 5 \\
\hline 3 & Odour & -- & -- & -- & -- & A \\
\hline 4 & $\begin{array}{c}\text { Turbidity } \\
\text { (NTU) }\end{array}$ & 2.13 & 2.09 & 2.19 & 2.13 & 1 \\
\hline 5 & $\begin{array}{c}\text { Specific } \\
\text { Conductivity } \\
(\mu \text { S/cm) }\end{array}$ & 292.6 & 296.3 & 294.5 & 294.46 & NG \\
\hline 6 & TDS (mg/L) & 175.56 & 177.78 & 176.7 & 176.68 & 500 \\
\hline 7 & pH & 6.2 & 6.3 & 6.4 & 6.3 & $6.5-8.5$ \\
\hline 8 & $\begin{array}{c}\text { Chloride } \\
(\text { mg/L) }\end{array}$ & 57.1 & 58.6 & 57.4 & 57.7 & 250 \\
\hline \multicolumn{7}{|c|}{ Heavy metal Concentrations for bore well water in mg/L } \\
\hline 9 & Barium & 2.00 & 2.32 & 2.12 & 2.14 & 0.7 \\
\hline 10 & Zinc & 2.16 & 2.09 & 1.95 & 2.06 & 0.05 \\
\hline 11 & Iron & 136.54 & 141.2 & 143.4 & 140.38 & 0.3 \\
\hline 12 & Manganese & 5.26 & 5.41 & 5.52 & 5.40 & 0.01 \\
\hline 13 & Lead & BDL & BDL & BDL & -- & 0.1 \\
\hline 14 & Chromium & BDL & BDL & BDL & -- & 5.0 \\
\hline
\end{tabular}

From the above table 3.7 it is seen that the samples of bore well water, barium, iron \& manganese concentration is greater than the desirable limits of BIS during the study period. Hence it can be said that the water sample can closely affect the people who use it for drinking purposes. The long-time usage of this water can affect the people leading to cardiovascular problems, taste/appearance including affects on water supply structures and cause adverse effects on human health respectively.

\section{CONCLUSIONS.}

- The leachate extracted from the WFS contains the concentrations of heavy metal, the examined concentrations when compared to the drinking water standard limits as per BIS 10500:2012. The heavy metal concentrations of iron- $35.21 \mathrm{mg} / \mathrm{L}$, lead- 0.77 $\mathrm{mg} / \mathrm{L}$ and manganese- $3.41 \mathrm{mg} / \mathrm{L}$ are extremely high in their values from the leachate extracted from WFS, when percolated through the ground, it contaminates the ground water quality. Other heavy metal concentrations such as barium, total chromium and zinc are not exceeding the values which could affect the water quality.

- The other Physico-chemical parameters such as temperature, colour, odour, turbidity, specific conductivity, total dissolved solids are all well within the limits of BIS 10500:2012.

- The concentration of heavy metal barium having the value in the range $2.001-2.321 \mathrm{mg} / \mathrm{L}$ and manganese in the range of $5.265-5.524 \mathrm{mg} / \mathrm{L}$ for bore well water sample, which exceeds the DL $-0.7 \mathrm{mg} / \mathrm{L}$ for the 
drinking water limits of BIS 10500:2012. The long term usage of this water for drinking purposes may lead to cardiovascular problems in human beings and it affects the taste/appearance of the water.

- The concentration of heavy metal iron having the value in the range of 136.54-143.4 $\mathrm{mg} / \mathrm{L}$ for bore well water sample, which exceeds extremely higher than the DL $0.3 \mathrm{mg} / \mathrm{L}$ for the drinking water limits of BIS 10500:2012. The long term usage of this water taste/appearance and it affects the sewer systems when used for longer duration.

- The concentrations of heavy metal such as barium, total chromium, iron for open well water sample, are well within the DL for the drinking water limits of BIS 10500:2012.

\section{ACKNOWLEDGEMENT.}

This acknowledgement is intended to be thanks giving to all those people who have been involved directly or indirectly with my work. The satisfaction that accompanies the successful completion of any task would be incomplete without the mention of my guide Associate Professor R B. Gadag, Department of Civil Engineering, KLE's Dr. M.S.Sheshgiri College of Engineering and Technology, Belagavi, who made it possible, whose constant guidance and encouragement crowned me all the efforts with success.

I would like to express my thanks and indebtedness to Principal B G. Katageri, Smt. B V. Chiniwalar H.O.D, and other professors, KLE's Dr. M.S.Sheshgiri College of Engineering and Technology, Belagavi, for their deep involvement, invaluable and continuous motivation throughout this work. I am highly obliged to them for being there always whenever I needed them.

\section{REFERENCES}

[1]. Attar I.M, A.K Gupta, "Application of foundry sand in Civil Engineering Construction”, IOSR, Journal of Mechanical and Civil Engineering, Vol 21, pp 38-42.

[2]. U.S EPA, American Foundry Society "Beneficial reuse of foundry sand" December-2002.

[3]. Rafat Siddique, Gurdeep kaur, Anita Rajor, "Waste foundry sand and its leachate characteristics” Journal of Resource Conservation and Recycling, Elsevier 2012, Vol 54, pp 1027-1036.

[4]. Rafat Siddique and Albert Noumowe, "Utilization of spent foundry sand in controlled low strength materials and concrete" Journal of Resource Conservation and Recycling, Elsevier 2008, Vol 53, pp 27-35.

[5]. Rafat Siddique, Gurdeep kaur, Anita Rajor, "Waste foundry sand and its leachate characteristics" Journal of Resource Conservation and Recycling, Elsevier 2012, Vol 54, pp 1027-1036.

[6]. "Standard Operation Procedures" Scientific Engineering Response and Analytical Services (SERAS), 2005, Vol 1831, pp 1-12.

[7]. " Standard Methods for the Examination of Water and Wastewater" American Public Health Association
(APHA), American Water Works Association (AWWA), Water Pollution Control Federation (WPCF), $16^{\text {th }}$ edition, American Public Health Association, Washington D.C, U.S.A 